\title{
Challenges Associated with Running a Green Business in India and Other Developing Countries
}

\author{
Sujaya H. ${ }^{1}$, Meghana Salins ${ }^{1} \&$ P. S. Aithal ${ }^{2}$ \\ ${ }^{1}$ Research Scholar, College of Management \& Commerce, Srinivas University, Mangalore, \\ ${ }^{2}$ College of Management \& Commerce, Srinivas University, Mangalore, India \\ Email: sujayaloknath@gmail.com
}

Type of the Paper: Explorative Research.

Type of Review: Peer Reviewed.

Indexed In: OpenAIRE.

DOI: http://doi.org/10.5281/zenodo.2654462.

Google Scholar Citation: IJCSBE

\section{How to Cite this Paper:}

Sujaya, H., Meghana, S. \& Aithal, P. S. (2019). Challenges Associated with Running A Green Business in India and Other Developing Countries. International Journal of Case Studies in Business, IT, and Education (IJCSBE), 3(1), 35-47.

DOI: http://doi.org/10.5281/zenodo.2654462.

International Journal of Case Studies in Business, IT and Education (IJCSBE)

A Refereed International Journal of Srinivas University, India.

(C) With Authors.

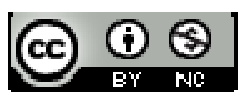

This work is licensed under a Creative Commons Attribution-Non Commercial 4.0 International License subject to proper citation to the publication source of the work.

Disclaimer: The scholarly papers as reviewed and published by the Srinivas Publications (S.P.), India are the views and opinions of their respective authors and are not the views or opinions of the S.P. The S.P. disclaims of any harm or loss caused due to the published content to any party. 


\title{
Challenges Associated with Running a Green Business in India and Other Developing Countries
}

\author{
Sujaya H. ${ }^{1}$, Meghana Salins ${ }^{1}$ \& P. S. Aithal ${ }^{2}$ \\ ${ }^{1}$ Research Scholar, College of Management \& Commerce, Srinivas University, Mangalore, \\ ${ }^{2}$ College of Management \& Commerce, Srinivas University, Mangalore, India \\ Email: sujayaloknath@gmail.com
}

\begin{abstract}
Running a green business in India and other developing economies is indeed a challenging job for the producers involved in this business. In a green business environment, the company may re-design the product attributes since the usage of the harmful chemical may be prevented and scarce resources may not be exploited. The main objective of this case study is to assess the factors that are associated with running a green business in India and other developing economies. This case study also highlights the issues related to the green business. This case study is developed by using secondary data to assess the factors that influence green business. The secondary data was obtained from another exhaustive literature review of journals and internet sources. The developing economies strive hard to achieve green business since it has been a necessity for these countries to depend on natural resources. The important aspect here is developing countries depend on both the economic and social factors which have a major impact on environmental factors. Moreover, developing countries are mainly dependent on natural resources for their potential and growth so as to give stiff competition for the developed economies in a global market. In addition, many developing economies face challenges basically related to power, water, ecological problems, social and economic problems and also problems related to weather and climate change. The challenges associated with green business also depends on cost analysis, where it is quite expensive for a poor and developing economy to reach the initial cost too since the usage of basic technology is lacking. Moreover, the treatment for wastewater, water resource management, treatment for disposal of effluents and toxic waste are not successfully utilized. The developed economies need to import modern technology and technical knowledge from other countries because of the lack of their own technology and technical skills. Now a day's many countries have the knowledge of green growth which thereby helps to improve the economic standards of the countries. The government has to take certain measures such as the provision of subsidies which may support the challenges of green growth and development. The short-term subsidies may not benefit more since it may hamper the production and demand by raising the price and cost. But as for the long term is considered these reforms may provide more effectiveness in productivity and thereby lead to changes in technologies.
\end{abstract}

Keywords: Green business environment, Challenging jobs, Developing economies.

\section{INTRODUCTION :}

The concept of green environment started during the 20th century because of consumers concern about environmental issues and scarcity which is aroused due to high utilization of natural resources where these resources may become scarce or depleted. Already it took long 20 years for the company to adopt this practice of green business [1]. In a developing economy doing a green business is no longer considered as a cost issue since it is now considered as a primary issue for modification and exploring of new markets and also profit maximization. In a green business environment, the 
company may re-design the product attributes since the usage of the harmful chemical may be prevented and scarce resources may not be exploited which thereby reduces the production and inventory cost. The company should adopt strategies and creative solutions to face the environmental challenges through mutual support from the policies of the companies and also by the provision of incentives by the government. The green behaviour is not only the sole concern of the consumers but also it is also the social responsibility of the producers to maintain their own green environment. One of the cleaning industries is striving hard to maintain progress in their job by developing efficiency towards energy usage. The US Institute of cleaning has shown the progress of about a $9 \%$ reduction in energy in the cleaning product and also 7\% decrease in emission of greenhouse gas from 2009 until 2 years.

The customers perceive that the green decisions are made due to personal reasons rather than global benefits and they feel that green products are much safer since it is considered as a protective measure for health and safety. In China $83 \%$ people consider important decision for purchasing behaviour is green environmental friendly reasons. Different countries try to solve the issues related to green decisions. The UK government have started introducing several schemes in their country to support green environment in order to meet the goal of reaching a target in the year 2020 of about $80 \%$ reduction in the emission of carbon dioxide.

The green movement will gain more importance when these practises are followed by both the employer and the employees. Since the task of practicing the green habits along with the employees is hardly difficult. So the company should ensure that the staffs follow this practice through coordination and communication and also by convincing them about the importance of green living. The workforces usually are not aware of the importance of the green change since they may be accustomed with the old policies where they may resist the new change. So these challenges should be met by the employer who is responsible to adapt the green environment which is very crucial for sustainability of business and environment.

There are several companies who are incapable to adopt the green changes in their work environment. Involving in green business is totally not an easy task for companies where there may be unsatisfactory level in the progress of the company. It's indeed very crucial for companies to utilize the opportunities of green practice so as to maintain their potential with the competitors and build a rapport with stakeholders.

\section{OBJECTIVES OF THE STUDY :}

The objectives of the study are limited to green business and its challenges in India and other developing countries.

(1) To explore the green business challenges at an international level

(2) To investigate the trends of green practices in India

(3) To analyze the benefits of the green movement in India

(4) To compare the production of green products with other countries.

\section{RESEARCH METHODOLOGY :}

This case study is developed on the basis of Published sources which are taken into consideration for the analysis of the data. The information about the green business and its challenges and practices in India and abroad is collected from the published sources. The main sources are international labour organization, National statistic and programme development, International business environment, life cycle Assessment based on waste management. In the case study the growth rate of green business, countries generate E-waste of the products internationally and environmentally friendly product and companies are taken in to consideration and analyzed.

\section{CONCEPTUAL FRAMEWORK OF THE STUDY :}

The concept of green business emerges from societal marketing [2]. The environmental consciousness based on green practices spreads among the consumers and modifications are to be made through different schemes such as ecolabelling, consumer guides, and groups [3]. Various literature shows that the studies based on green practice and business are formally done in developed 
economies but studies do not show more about the green environmental issues adopted in the business of developing economies.

\section{Green marketing mix:}

\section{(1) Green products}

The green products basically last long with low toxic level and made out of recycled items and a low packaged product [4]. So green marketing is a business which comprises recycling, low packaging material, raw materials which are sustainable, re-usage, easy repairs, safe disposal, and safer products for usage and environment [5-7].

\section{(2) Green price}

The customers pursue that green products are costlier when compared to other products [8-9]. Green pricing concept often ensures productivity of company along with health issues of the consumers and public. In shopping malls, some of the big companies charge certain prices for the customers who preferred plastic bags and supported eco-friendly bags.

\section{(3) Green place}

The green place is basically related to shortening the distribution cost whereby lowering the carbon effect on the environment. The country should produce their own production of finished products instead of purchasing from another country by way of transportation and also reduction in the cost of shipment of goods and other methods of transportation in order to reduce the carbon effect on the environment.

\section{(4) Green promotion}

Green practices and promotion help in providing information about the environment. According to [10-11] to reduce the gap of promotion and environmental information several plans are set [12].

\section{ANALYSIS/RESULTS :}

Green growth is considered crucial for economic development and also to control the depletion of natural resources and to tackle the poverty level and develop the environmental policy. The organization for economic corporation and development has started to prepare the various reports regarding the changes in policies based on green environmental practices. The developing economies play a crucial role in attaining world green environment. The developing economies are dependable to the natural inputs for their economic development compared to developed economies where the resource may be scarce or depleted, moreover they face certain risks such as scarcity of food, power and water supply and climatic disorders including increase in death rate due to usage of contaminated drinking water, environmental pollution, overpopulation, lack of rainfall due to deforestation and sickness related climatic conditions which affect the development of the population. The developing economies contribute fewer shares in the green practices compared to developed economies .The emission rate may increase if the organic method of cultivated is not adopted by the developing economies.

Globally some countries have started to concentrate on global environmental issues by setting certain targets on environmental green practices for bringing change in the reduction of depletion of natural resources. The Environmental Performance index is set by countries in the year 2016 and compared with different countries.

Table 1: The Chart of Environmental Performance Index (EPI) of Countries 2016 -17

\begin{tabular}{|l|l|}
\hline Country & EPI Index \\
\hline Finland & 90.51 \\
\hline Iceland & 90.43 \\
\hline Sweden & 89.21 \\
\hline Slovenia & 88.98 \\
\hline Spain & 88.91 \\
\hline Portugal & 88.63 \\
\hline Estonia & 88.59 \\
\hline Malta & 88.48 \\
\hline
\end{tabular}




\begin{tabular}{|l|l|}
\hline France & 88.2 \\
\hline New Zealand & 88.0 \\
\hline United Kingdom & 87.38 \\
\hline Australia & 87.22 \\
\hline Singapore & 87.04 \\
\hline Croatia & 86.98 \\
\hline Switzerland & 86.93 \\
\hline Norway & 86.9 \\
\hline Austria & 86.64 \\
\hline Ireland & 86.6 \\
\hline Luxemburg & 86.58 \\
\hline
\end{tabular}

Source: European countries top Yale's environment index 2016-17

\section{Green customers/companies}

The green customer is more concerned about environmental issues and for this reasons they purchase the green products and are more open-minded towards the green purchase and believe it is the duty of customers to maintain this standard rather than feeling that it is the job of the government, companies or environmentalist [13]. The business too has tried to develop this green standard and is trying to speed up with their green policies since the customers eventually started to notice the green labels on the goods sold in the malls and shopping centres. The green practices of customers have affected the business profits and sales. In this regard, some of the airways have tried to provide funding to the researchers who find a solution for the emission of carbon since the air transport releases the maximum amount of carbon emission into to the planet where environmental friendly customers can donate funds for the problems.

\section{THE TOP GREEN COMPANIES IN INDIA :}

Table 2: The top Green companies of India with reduction of carbon footprints

\begin{tabular}{|l|l|l|l|}
\hline Rank & $\begin{array}{l}\text { Green } \\
\text { Score }\end{array}$ & Company & Sector \\
\hline 151 & $56.1 \%$ & Tata Consultancy Services & Information Technology \\
\hline 185 & $52 \%$ & Infosys & Information Technology \\
\hline 351 & $27.2 \%$ & Housing Development Finance & Financials \\
\hline 352 & $27.2 \%$ & Sun Pharmaceutical Industries & Health Care \\
\hline 357 & $26.4 \%$ & ITC & Consumer Staples \\
\hline 373 & $24.5 \%$ & Hindustan Unilever & Consumer Staples \\
\hline 437 & $17.7 \%$ & ICICI Bank & Financials \\
\hline 438 & $17.6 \%$ & Reliance Industries & Energy \\
\hline 445 & $17 \%$ & HDFC Bank & Financial \\
\hline 449 & $16.3 \%$ & State Bank of India & Financials \\
\hline
\end{tabular}

\section{Source: Newsweek}

There are many green companies in the world such as Shire PLC Company of Ireland, Benckiser Company of UK and some of the companies of France, Switzerland, and Germany are in the top list India is one producer of green products producing and export them to different countries. These companies follow the` go green practices along with rapid growth in the productivity and environmental concern. The Tata Consultancy services are the top scorer with the rank $56.1 \%$ followed by Infosys with 52\% and Housing development Finance with 27.2\%. The Financial services such as ICICI banks and HDFC and State Bank of India also follow green practices.

\section{Product design innovation :}


The companies which are environmental friendly utilize the resources effectively to maintain productivity and to control the higher level of waste and in order to modify the products attributes different strategies are adopted by companies to decrease the effects of environmental degradation. The companies provide to the vendor's necessary product designs with regard to environmental needs and audits. [14-15] the company also coordinate with the vendors to develop the tools equipment and the services that support the environmental objectives and along with its provision of training and educating the vendors.

\section{Recycling :}

The companies which give more importance for the environmental issues try to minimize the waste, wear and tear and recovery of investment. These companies coordinate with the local or other networks companies which recycle products and also with similar industries. They also provide sufficient education about the disposal of effluents and recycling of products. They also render the services regarding the provision of education about the environmental practices to various retailers and the distributors and also the customers. The companies try to avoid wrong practices of effluents disposal and following the modern techniques of the process in order to improve the rate of recycling.

Table 3: The Countries winning recycled race- 2013-14

\begin{tabular}{|l|l|}
\hline Country & Recycling rate in \% \\
\hline United States & 35 \\
\hline Austria & 58 \\
\hline Germany & 65 \\
\hline Taiwan & 60 \\
\hline Singapore & 59 \\
\hline South Korea & 59 \\
\hline Luxemburg & 48 \\
\hline United Kingdom & 43 \\
\hline Italy & 41 \\
\hline France & 35 \\
\hline Netherland & 50 \\
\hline Sweden & 50 \\
\hline Denmark & 44 \\
\hline Finland & 33 \\
\hline Israel & 19 \\
\hline Wales & 64 \\
\hline Switzerland & 51 \\
\hline Mexico & 5 \\
\hline Poland & 29 \\
\hline
\end{tabular}

Source: The recycled and composted waste as a share of total municipal waste in OECD countries

\section{E-Waste - From Toxic to green :}

In order to prevent the carbon and other gases released to air, more than 17 tonnes of the e-waste is collected every year. The e-waste which is not utilized may generate greenhouse emissions. The main aim of the developed countries is to dispose of the effluents and reduce waste through recycled programmes. There are informal waste pickers who help in cleaning the countries cities where they do not have formal recognition, rights, and dignity. More than 2,000 waste pickers are trained in order to collect waste from different areas. Also, these people collect e-waste from non-motorized vehicles and old computers. Recent studies have shown that in the US 315 Million computers in 2004-5 will become discarded. More than 6,000 computers are discarded every day in California and that is the reason E-waste is increasing at a speed rate. 


\section{International Journal of Case Studies in Business, IT, and Education SRINIVAS (IJCSBE), ISSN: 2581-6942, Vol. 3, No. 1, April 2019.

The problem of E-waste is limited to industrialized worlds. The IT industry had an annual growth of more than 42.4\% With 13 Million phones and 70 Million Television which will be E-waste. Reports also show that illegal export trade of E-waste considers India, Pakistan, and China the favourite destination. According to the report, $50-80 \%$ of the E-waste is totally collected from developing economies like China, India, Vietnam, Philippines and a smaller amount to the African countries such as Nigeria due to low labour cost and liberal regulations of these countries. So E-waste has become a challenge to the developing economies India is becoming a dumping yard for many electronic and electrical products. The government has set some regulation based on E-waste in 2016 whereby the producers are made responsible for the collection of E-waste and send it for recycling. The government had set rules for the reduction of Hazardous elements such as lead, mercury etc. The Handling of E-waste is not applied to lead-acid batteries. India has major quantity of toxic and hazardous E-waste of about 18 lakh tonnes moreover the process of recycling has laid some guidelines which were published by the pollution control board of India since E-waste can be recycled $99 \%$ but the E-waste is thrown to the dump yard and the developed economies are making developing country their dumping yards. This is the reason India in 2020 will generate nearly I, 00,000 tonnes of E-waste and our India will extract precious metals like gold silver and platinum from E-waste and shipping it to Japan, Belgium, and Singapore in a year. The developed countries are dumping the E-waste in the Arabian Sea which has affected biodiversity and ecosystem of the countries.

Table 4: Top 10 countries by the amount of E-waste generated in 2016-17

\begin{tabular}{|l|l|l|}
\hline Rank & \multicolumn{1}{|c|}{ Country } & $\begin{array}{l}\text { E-waste Generated (million Metric } \\
\text { tons)2016 }\end{array}$ \\
\hline 1 & China & 7.2 \\
\hline 2 & United states & 6.3 \\
\hline 3 & Japan & 2.1 \\
\hline 4 & India & 2.0 \\
\hline 5 & Germany & 1.9 \\
\hline 6 & Brazil & 1.5 \\
\hline 7 & Russia & 1.4 \\
\hline 8 & France & 1.4 \\
\hline 9 & Indonesia & 1.3 \\
\hline 10 & Italy & 1.2 \\
\hline
\end{tabular}

Source: The Global E-Waste Monitors 2017

The Table suggests that the United States and China top the rate with the highest mark of 7.2 and 6.3 million metric tons respectively with aggregate figure followed by Japan and India with 2.1 and 2.0 respectively and Indonesia and Italy with the least E-waste generation.

\section{GREEN BUSINESS GROWTH FROM GLOBAL PERSPECTIVE :}

\subsection{Global Green Business growth:}

Due to the globalization of green goods, the growth of these products have increased in number and presently it accounts for 9 lakh job in the United Kingdom and other countries, The business houses assume that green production increases the opportunities for development; moreover developing countries are showing interest in investing in research and development of green growth. The developed economies such as Germany have increased its revenue due to the development of green growth. The present and existing entrepreneurs are entering into a green segment for expansion and development of their businesses. The financial institutions and banks also support these business entities for funding purposes. By controlling the environmental degradation the government may set liberal rules for the green investors. This is an opportunity for business houses to eliminate waste and reduce the production cost of green goods. Through the global perspective, the business can learn a lot about green investment, their opportunities, and growth. 
Training and development can help these business houses to take crucial decisions based on green growth. According to the research report, the global perspective will increase the potential of the management teams. After the 2000s there was a rapid change in income of the developing economies due to a global green environment. If this process goes for a long way when there are changes in more progress towards achieving growth and development in around the coming years. The green growth, however, provides opportunities for sustaining stability, job creation, and increase in GDP, reduction in poverty and waste resources and also changes in consumption pattern. The government has set a framework based on usage of renewable resources, attract foreign investors in the green business, and give support for the establishment of green markets, mergers, and acquisitions with foreign companies. The countries like Kenya and Uganda have started their own electricity sectors and thereby creating positive effects on green energy resources. It is also quite difficult to obtain financial accommodation for renewable resources and the green investors have to defend on banking loans which may not be available easy, that is the reason green investors totally depend on the project finance where risk is involved and green investors show disinterest in investing in green businesses.

Table 5: The top 10 countries showing Green business growth from global perspective

\begin{tabular}{|l|l|l|}
\hline Rank & \multicolumn{1}{|c|}{ Country } & Score \\
\hline 1 & Sweden & 68.1 \\
\hline 2 & Norway & 65.9 \\
\hline 3 & Costa Rica & 64.2 \\
\hline 4 & Germany & 63.6 \\
\hline 5 & Denmark & 63.2 \\
\hline 6 & Switzerland & 63.1 \\
\hline 7 & Austria & 63.0 \\
\hline 8 & Finland & 62.9 \\
\hline 9 & Iceland & 62.6 \\
\hline 10 & Spain & 59.2 \\
\hline
\end{tabular}

Source: Global Green Economy Index, Dual Citizen LLC

The index suggests that some of the fastest growing economies are not involved in green policy. Countries like UAE, Cambodia, Thailand, china and other Middle East countries like Qatar show disinterest in these policies.

\subsection{Comparative study of the green products in India with Other Countries:}

The word 'green' is gaining more popular among the new generation. The various businesses are showing more interest in the green concept. The countries like America, the United Kingdom, China, India, Canada, and Germany are showing more interest in environmental issues. But the green idea is expensive for both the company and consumers and eventually it is more profitable to businesses and environment for the long run. From the recent survey, India ranked 155 places with a comparison of other countries with regard to environmental pollutions. Compared to the BRICS counties where India is one of the members with other four countries. India`s environmental quality is more below the other BRICS countries. It is indeed a problem and a challenge for the business houses which practices green concept. Such as the literacy level of the consumers where the customers should be made aware of the green products and convincing the customers about the green products since the product are expensive, spending on R\&D, avoiding the unethical issue to make profits.

The consumers have exposed to good and a healthy lifestyle with consumption of green products and Yoga. Controlling the waste factor in green concept is also considered mandatory since recent report suggest that waste generation may increase in the future when compared to the present and if it is not controlled than it may hamper the life and environment to a large extent. When compared to countries like the UK, it has successfully designed some programme of waste reduction and green production. Recycling of goods is successfully done with the help of a collection of waste from every household. Reducing the waste in the UK has become a prolonged process along with the usage of modern infrastructure. India is emerging with the new green concept and waste management. 
Table 6: Most recognised environmental assessment of the world`s largest publicly traded companies of the world.

\begin{tabular}{|l|l|l|}
\hline Rank & \multicolumn{1}{|c|}{ Company } & Score \\
\hline 1 & $\underline{\text { L'Oreal SA }}$ & $\underline{89.90 \%}$ \\
\hline 2 & $\underline{\text { Centrica PLC }}$ & $\underline{88.70 \%}$ \\
\hline 3 & $\underline{\text { Enbridge Inc }}$ & $\underline{86.00 \%}$ \\
\hline 4 & $\underline{\text { Siemens AG }}$ & $\underline{85.30 \%}$ \\
\hline 5 & $\underline{\text { Cisco Systems Inc }}$ & $\underline{83.70 \%}$ \\
\hline 6 & Henkel Ag \& Co & $\underline{82.60 \%}$ \\
\hline 7 & $\underline{\text { Accenture PLC }}$ & $\underline{82.50 \%}$ \\
\hline 8 & $\underline{\text { BT Group PLC }}$ & $\underline{82.50 \%}$ \\
\hline 9 & $\underline{\text { Adidas AG }}$ & $\underline{79.60 \%}$ \\
\hline 10 & $\underline{\text { Koninklijke Philips NV }}$ & $\underline{77.90 \%}$ \\
\hline
\end{tabular}

Source: Newsweek Green Score

\section{SWOC ANALYSIS OF RUNNING A GREEN BUSINESS INDIA :}

The industrial internal analysis can be done using many analytical methods which include, SWOC Analysis [16-17], BCG Matrix [18], ABCD Analysis [19-20], Six Thinking Hats [21-22], PEST analysis [23], Ideal system model-based analysis [24],Competitive forces analysis [25] Predictive analysis [26] etc. These analytical methods usually qualitative in nature, used to identify industry problems, status, or facts related to industry/organization /issue under consideration. The SWOC analysis reveals the internal status of the industry and in this study. We have studied the strengths, weakness, opportunities, and challenges of running a green business India.

Table 7: Depicts the SWOC analysis of running a green business India

\begin{tabular}{|c|c|}
\hline Constraints & Features \\
\hline $\begin{array}{l}\text { Strengths on running a green } \\
\text { business in India }\end{array}$ & $\begin{array}{l}\text { Green business are found to be friendly towards environment } \\
\text { Company can gain a good reputation and image towards brands } \\
\text { Can increase customers awareness towards products } \\
\text { Producers and farmers gain lot of benefits through green } \\
\text { practice }\end{array}$ \\
\hline $\begin{array}{l}\text { Weakness on running a } \\
\text { green business in India }\end{array}$ & $\begin{array}{l}\text { Most of the industries have to follow a long process and spend } \\
\text { heavy cost in order to obtain the certificate for environmental } \\
\text { issues } \\
\text { The small players are not in a position to promote this product } \\
\text { Common awareness about the green business is lacking among } \\
\text { Indians. } \\
>\text { Major chunks of profits goes to the middle mans pocket } \\
\text { There is lack of sufficient regulation and frame work from the } \\
\text { government authority. }\end{array}$ \\
\hline $\begin{array}{l}\text { Opportunities for running a } \\
\text { green business in India }\end{array}$ & $\begin{array}{l}>\text { Company can attain competitive advantages towards other } \\
\text { products by increasing sales } \\
>\text { By creating awareness of the product existence company can } \\
\text { gain more profits } \\
>\text { Provision of better prospects and subsidy by government in } \\
\text { order to improve the customer base } \\
>\text { The business can go internationally through producing } \\
\text { environmental friendly products by recycling methods }\end{array}$ \\
\hline $\begin{array}{l}\text { Challenges for running a } \\
\text { green business in India }\end{array}$ & $\begin{array}{l}\text { Facing stiff competition from the worldwide. } \\
\text { Company need to wait for long term benefits from the } \\
\text { government. }\end{array}$ \\
\hline
\end{tabular}




\section{\begin{tabular}{|l|l}
\hline & the masses
\end{tabular}}

$>$ Majority of the people in India are not much concerned about environmental issues.

The swot analysis depicts the weakness, challenges and treats the company which have to face along with the opportunities to explore in the competitive markets in domestic as well as global level. The company's main goal is to analyse the risk factors which emerges due to various constraints based on internal and external factors and collect various information regarding the problems of companies and try to seek out issues with the help of decision makers who thereby select the best option among the alternatives. Under the ABCD analysis different set of issues can be analysed which is simple and demonstrate various issue pertaining to the problems which gain Access to solution by measures of factor and element analysis and thereby analysing the company future prospect, strategies, ideas and services of the company. Now a day's company's main goal is business research along with profit maximisation which has created a rapid influence on training market of education worldwide. The consultative companies have thereby created an opportunities with its business schools along with various research initiative in their professional service sectors with small courses as a training measure. The advantages, benefits constraints and disadvantages (ABCD) analysis models can be compared with other framework such as porter`s models, PEST analysis and also SWOT analysis to identify the environmental factors and competitive edge of companies. Company with green habits find the environment as a big challenge since it is quite a big job to sustain trust of consumers. The consumer's wrong perception may create damage for company reputation and affect the brand image moreover the consumer demand may shift to some substitute product. The territory sector can have competitive advantage by way of usage of modern sophisticated technology. Environmental studies have gained more importance in higher education since it acts as a link between higher education and environmental factors. The dispose of effluents and degradation have led to imbalance in the environment since the oxygen released by plants and trees are been utilized by humans and animals for survival. But due to excess mushrooming of industrial sectors deforestation have increased which have led to reduction in oxygen level. The green technologies lead to sustainability of organic inputs and reduction in green gasses where the degradation of resources can be prevented through green practices of companies. [27-34].

\section{FINDINGS OF THE STUDY :}

1. The developing economies contribute fewer shares in the green .practices compared to developed economies.

2. The green practices of customers have affected the business profits and sales positively.

3. The studies reveal that aged people are more concerned about environmental issues rather than youngsters.

4. Studies show that in a developing economy doing a green business is no longer considered as a cost issue since it is now considered as a primary issue.

5. From the study we notice that company adopts strategies and creative solutions to face the environmental challenges through mutual support from companies and also by the provision of incentives by the government.

6. India has major quantity of toxic and hazardous E-waste of about 18 lakh tonnes and the process of recycling has laid some guidelines which were published by the pollution control board of India.

7. Recent report suggest that waste generation may increase in the future when compared to the present and if it is not controlled than it may hamper the life and environment to a large extent.

\section{SUGGESTIONS AND RECOMMENDATIONS :}

(1) Growing pressure over environmental concerns in the world has led to global issues which have a high impact on the population and the environments, the various problems such as disposal of effluents, a forestation, utilization of scarce resources, polluted water, under utilization of agriculture land has led to great disaster in the ecological balance. So the usage of recycled product may create a major change in the ecological factor which there by lead to reduction in the environmental threats 
and degradation of resources. So awareness should be created in the countries which adopt the green policies in business.

(2) The companies tend to increase the production of green business so that it can give a competitive edge to all the countries at global level. Awareness towards green environment and green jobs should be increased in national as well as international level and also to increase the green customers by providing education of the green concept.

(3) The government should set up certain schemes which may provide support to green practices and to set a target which should be reached within a particular period. Modification in the regulation should be made so that the companies can export majority of the green products both in domestic as well as international level

(4) Efforts should be made to change the behaviour and attitude of the customer to stick towards recycled products. Since studies reveal that the aged people are more concerned about environmental issues and use public transport instead of their own vehicle for travelling unlike the young generation. So that younger generation should be more exposed towards green habits and green purchasing intentions.

\section{CONCLUSION :}

The studies reveal that now a day's companies stick towards green practices to gain a competitive edge over other countries by giving more attention to the organic environment. They consider that environmental issue is a major factor to sustain the social responsibility. The companies are also aware of the key issues of green practices and in order to survive in this global era, the green environment has become a crucial concept. The studies confirm that regarding going green in developing new products has become a necessity for companies due to government policies, stiff competitive forces, and modernization of technologies, product innovation, safety etc in the domestic and global level. Research also reveals how green practices affect market shares in both the national and international level. It also reveals how it effects in a positive and negative way towards factors such as waste management, product modification, disposal of effluents, usage of resources which are renewable, cutthroat competition, increased market share, climate change etc. Studies also show company investing in the secondary sector thrives to invest more in the research and development in order to bring change in the green concept. Finally, in order to attain sustainable advantage, the producers and the suppliers maximize the positive effects of green practices in green business both in India and other developing countries. The study also concludes how all the sector should go green to face the challenges and the threats in a long time prospects. The only way forward is to achieve growth through innovative technologies and promote sustainable mobility. The studies also recommend that automobile producers have started to invest in research and the development dedicated to 'green innovation.' These green policies are expected to sort out issues of fuel emissions and efficiency - reducing consumption of fuel and greenhouse gas effects.

\section{REFERENCES :}

[1] Shefali Rai, sayali Jambhulkar (2018). An analytical study of green business practices in India with specific reference to selected Indian company. International journal in Management and Social Science,6(9), 2321-1784. DOI: https://doi.org/37609006.

[2]. Kotler (1999). Exploring consumer attitude and behaviour towards green practices in the lodging industry in India. International Journal of Contemporary Hospitality Management, 19(5), 364-377. DOI: https://doi.org/10.1108/09596110710757534.

[3] Ken Peattie, Andrew Crane (2005). Green marketing: Legends, myth, farces or prophesy? Qualitative Market Research - An International Journal, 8(40), 357-370. DOI: https://doi.org/10.1108/13522750510619733.

[4] Jacquelyn A. Ottman (1992). Industry's Response to Green Consumerism. Journal of Business Strategy, 13(4), 3-7. DOI: https://doi.org/10.1108/eb039498. 
[5] Vasanthakumar N. Bhat, Ashley, Polonsky (1993). Green Marketing Begins with Green Design. Journal of Business \& Industrial Marketing, 8 (4), 26-31, DOI: https://doi.org/10.1108/08858629310047243.

[6] Michael Jay Polanski (2011). Transformative green marketing: Impediments and opportunities. Journal of Business Research 64(12), 1311-131. DOI: https://doi.org/10.1016/j.jbusres.2011.01.016.

[7] Peattie (1999). Towards Sustainability: The Third Age of Green Marketing. The Marketing Review. West burn Publishers Ltd, 2(2), 121-146, https://doi.org/10.1362/1469347012569.

[8] Shamdasani (1993). In Search Of the Green Consumers: A Perceptual Study. Journal of Services Research, 7 (7), 173-191.

[9] Darn all, Zhu (2005). How international is corporate environmental responsibility. Journal of International Management, 18(2), 19, DOI: https://doi.org/10.1016/j.intman.2012.02.001.

[10] Hu \& Hsu (2010). An analysis of the drivers affecting the implementation of green supply chain management Resources. Conservation and Recycling, 55(6), 656-667. DOI : https://doi.org/10.1016/j.resconrec.2010.12.002.

[11] Kapetanopoulou \& Tagaras (2011). Managing Organizations for Sustainable Development in Emerging Countries. International Journal of Sustainable Development \& World Ecology 21(3), 235-245, DOI : https://doi.org/10.1080/13504509.2014.906003.

[12] Wu \& Dunn (1995). Identifying and ranking of strategies to implement green supply chain management in Indian manufacturing industry using Analytical Hierarchy Process. Journal of Industrial Engineering and Management 6(4), 930-962. DOI: http://dx.doi.org/10.3926/jiem.69:

[13] Humphrey, A. S. (2005). SWOT analysis. Long Range Planning, 30, 46-52.

[14] Aithal, P. S. \& Suresh Kumar, P. M. (2015). Applying SWOC Analysis to an Institution of Higher Education. International Journal of Management, IT and Engineering (IJMIE), 5(7), 231247, DOI : http://doi.org/10.5281/zenodo.163425.

[15] Henderson, B. D. (1979). The product portfolio: growth share matrix of the Boston Consulting Group. The strategy process, Concepts, contexts, cases, 678-680.

[16] Aithal, P. S. (2016). Study on ABCD Analysis Technique for Business Models, business strategies, Operating Concepts \& Business Systems. International Journal in Management and Social Science, 4(1), 98-115, DOI : http://doi.org/10.5281/zenodo.161137.

[17] Aithal, P. S., Shailashree, V.T. \& Suresh Kumar, P.M. (2015). A New ABCD Technique to Analyze Business Models \& Concepts. International Journal of Management, IT and Engineering (IJMIE), 5(4), 409 - 423, DOI: http://doi.org/10.5281/zenodo.61652.

[18] De Bono, E. (1999). Six Thinking Hats, Back Bay Books, New York.

[19] Aithal, P. S. \& Suresh Kumar, P. M. (2017). Lateral Thinking in Managerial Decision Making Through Six Thinking Hats Technique. International Journal of Scientific Research and Modern Education (IJSRME), 2(1), 53-58, DOI : http://dx.doi.org/10.5281/zenodo.438149.

[20] Aithal, P. S. \& Suresh Kumar, P. M. (2017). Ideal Analysis for Decision Making in Critical Situations through Six Thinking Hats Method. International Journal of Applied Engineering and Management Letters (IJAEML), 1(2), 1-9, DOI : http://dx.doi.org/10.5281/zenodo.838378.

[21] Gupta, A. (2013). Environment \& PEST analysis: an approach to external business environment. International Journal of Modern Social Sciences, 2(1), 34-43.

[22] Aithal, P. S. (2016). Review on Various Ideal System Models Used to Improve the Characteristics of Practical Systems. International Journal of Applied and Advanced Scientific Research, ISSN: 2456-3080, 1(1), 47-56, DOI : http://doi.org/10.5281/zenodo.159749. 
[23] McMillan, C. (2010). Five competitive forces of effective leadership and innovation. Journal of Business Strategy, 31(1), 11-22.

[24] Aithal P. S. \& Shubhrajyotsna Aithal (2018). Factor \& Elemental Analysis of Nanotechnology as Green Technology using ABCD Framework. International Journal of Management, Technology, and Social Sciences (IJMTS), 3(2), 57-72. DOI : https://doi.org/10.5281/zenodo.1451490.

[25] Aithal, P. S. (2017). An Effective Method of Developing Business Case Studies based on Company Analysis, International Journal of Engineering Research and Modern Education (IJERME), 2(1), 16-27. DOI: http://dx.doi.org/10.5281/ZENODO.400579.

[26] Aithal, P. S. (2017). Company Analysis - The Beginning Step for Scholarly Research. International Journal of Case Studies in Business, IT and Education (IJCSBE), 1(1), 1-18. DOI: http://dx.doi.org/10.5281/zenodo.573769.

[27] Aithal, P. S. (2017). Industry Analysis - The First Step in Business Management Scholarly Research. International Journal of Case Studies in Business, IT and Education (IJCSBE), 2(1), 113. DOI: http://dx.doi.org/10.5281/zenodo.810347.

[28] Aithal, P. S. (2017). ABCD Analysis as Research Methodology in Company Case Studies. International Journal of Management, Technology, and Social Sciences (IJMTS), 2(2), 40-54. DOI: http://dx.doi.org/10.5281/zenodo.891621.

[29] Aithal, P. S. \& Priti Jeevan (2016). Strategic Rethinking of Management Education : Green MBA Model. International Journal of Management, IT and Engineering (IJMIE), 6(1), 55-73._DOI: http://doi.org/10.5281/zenodo.154278.

[30] Aithal, P. S. (2016). Study on ABCD Analysis Technique for Business Models, business strategies, Operating Concepts \& Business Systems, International Journal in Management and Social Science, 4(1), 98-115, DOI: http://doi.org/10.5281/zenodo.161137.

[31] Aithal, P. S. \& Preethi J. (2016). How Service Industries can Transform themselves into Green Business Industries. International Journal of Management Sciences and Business Research (IJMSBR), 5(4), 150-158, DOI: http://doi.org/10.5281/zenodo.161114.

[32] Prithi Rao, and Aithal, P. S. (2016). Green Education Concepts \& Strategies in Higher Education Model. International Journal of Scientific Research and Modern Education (IJSRME), 1(1), 793802. DOI: http://doi.org/10.5281/zenodo.160877.

[33] Sridhar Acharya, P. \& Aithal, P. S. (2016). Impact of Green Energy on Global Warming - A Changing Scenario, International Journal of Scientific Research and Modern Education (IJSRME). 1(1), 838-842. DOI: http://doi.org/10.5281/zenodo.154575.

[34] Aithal, P. S. and Shubhrajyotsna Aithal (2016). Opportunities \& Challenges for Green Technology in $21^{\text {st }}$ Century. International Journal of Current Research and Modern Education (IJCRME), 1(1), 818-828. DOI : http://doi.org/10.5281/zenodo.62020.

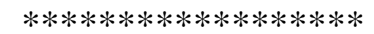

